\title{
A comparison of different rinsing methods upon selective dissolution of iron (oxy)hydroxides in soils/sediments
}

The Mining-Geology-Petroleum Engineering Bulletin UDC: 543.2:549.5:502.3/7. DOI: 10.17794/rgn.2017.2.2

Original scientific paper

\author{
Marija Čambala ${ }^{1}$, Michaela Hruškova-Hasan ${ }^{2}$, Marta Mileusnićc \\ University of Zagreb, Faculty of Mining, Geology and Petroleum Engineering, Department of Mineralogy, Petrology and Mineral Resources, \\ Pierottijeva 6, HR-10000 Zagreb, Croatia \\ ${ }^{1}$ student; ${ }^{2}$ professional associate (head of laboratory); ${ }^{3}$ Associate Professor
}

\begin{abstract}
Iron (oxy)hydroxides play an important role in a variety of disciplines, among others, environmental and exploration geochemistry, mineralogy, geology and soil science. In selective leaching procedures, either for the removal of (oxy)hydroxide prior to clay minerals analysis or for the determination of metals in reducible soil/sediment fractions, it is very important to preserve the entire undissolved residue. Therefore, the objectives of the study were: (1) to find the most effective reagent rinsing method which follow the dissolution of (oxy)hydroxides; and (2) to test if the content of Fe (oxi) hydroxides could be determined gravimetrically. The following reagent rinsing methods were tested: (1) centrifugation, (2) filtration, (3) dialysis. The analysis was conducted on the sample of red soil with $5 \cdot 12 \% \mathrm{Fe}_{2} \mathrm{O}_{3}$. The time needed for rinsing increased in this order: centrifugation < filtration < dialysis. The amount of gravimetrically determined dissolved reducible fraction upon rinsing varies significantly depending on the methods and it is remarkably higher than the amount of $\mathrm{Fe}_{2} \mathrm{O}_{3}$ calculated from iron content determined by atomic absorption in leachate. The most effective reagent rinsing method which follows the dissolution of (oxy)hydroxides using dithionite-citrate-bicarbonate is dialysis. No loss of sample is the advantage of this method, but its disadvantage is time needed for its completion. Centrifugation is relatively rapid, but can lead to loss of the smaller particles. In this case the loss was unacceptably great. Filtration using filter paper is more time consuming than centrifugation and it showed the worst results. The conclusions are that: (1) the content of $\mathrm{Fe}$ (oxi)hydroxides cannot be determined gravimetrically upon selective leaching; (2) rinsing of reagents after Fe (oxi)hydroxide removal prior to clay mineral analysis should be carefully selected and performed; (3) centrifugation, accepted rinsing method in all sequential extraction sequences, can cause misleading results.
\end{abstract}

\section{Keywords}

Iron (oxy)hydroxides, rinsing, centrifugation, filtration, dialysis

\section{Introduction}

Iron (oxy)hydroxides play an important role in a variety of disciplines, including pure, environmental and industrial chemistry, corrosion science, mineralogy, geology, soil science, planetology, biology and medicine. Fifteen iron (oxi)hydroxide minerals are known to date. They differ in composition, in the valence of $\mathrm{Fe}$ and, above all, in crystal structure. Iron oxides are widespread in nature and they are of great significance for many of the properties and processes taking place in ecosystems (Schwertmann and Cornell, 2000).

In soils and sediments (oxi)hydroxides exist as nodules, concretions, cement between particles, or simply as a coating on particles (Tessier at al., 1979). They regulate the concentration of plant nutrients such as phosphate and inorganic (heavy metals) and organic pollutants and function as an adsorbent and an electron accep-

Corresponding author: Marta Mileusnić

marta.mileusnic@rgn.hr tor during dissimilatory metabolism of micro-organisms under anoxic conditions. The iron oxides in natural surface environments are often poorly crystalline, i.e. the crystals are nano-sized, do not clearly exhibit the typical morphology of well-crystalline forms, are rich in defects and contain impurities. Due to their striking colors (ranging from red to yellow) and their high surface area, small concentrations of (oxi)hydroxide color the soils and rocks in which they are mixed (Schwertmann and Cornell, 2000).

The identification of Fe (oxi)hydroxides in soil by $\mathrm{X}$-ray diffraction (XRD) may be complicated due to their small amounts, overlapping of diagnostic lines with those of associated minerals and the poor crystallinity of some phases (Durn et al., 2001). For identification and even quantification of secondary Fe (oxi)hydroxides in soils, several selective dissolution treatments can be used. The most useful among them are an acid ammonium oxalate treatment and dithionite-citrate bicarbonate (DCB) treatment. The former treatment dissolves only poorly crystalline phases, predominately fer- 
rihydrite (Schwertmann, 1964; Schwertmann et al., 1982; Schwertmann and Taylor, 1989), while the dithionite-citrate bicarbonate treatment proposed by Mehra and Jackson (1960) dissolves practically all secondary Fe (oxi)hydroxides (Schwertmann and Taylor, 1989). Quantification of Fe (oxi)hydroxides is done by analysing iron content in a solution after selective dissolution.

As (oxi)hydroxides are excellent scavengers for trace metals (Tessier at al., 1979; Burgos et al., 2012), different (oxi)hydroxide selective dissolution treatments are used in selective leaching schemes for soil and sediments. These treatments are used for pollutant release assessment in the frame of environmental geochemistry, as well as for ore deposits prospection in the frame of exploration geochemistry. Except earlier mentioned reagents, as Fe (oxi)hydroxides are thermodynamically unstable under anoxic conditions (i.e., low Eh), other strong reducing agents are used (e.g. hydroxylamine in hydrochloric acid; sodium-EDTA) (e.g. Borggaard, 1979; Miko et al., 2003; Mileusnić et al., 2014).

In selective leaching procedures, regardless of the purpose (removal of (oxy)hydroxide prior to clay minerals analysis or determination of metals in soil/sediments sequential fractions, it is very important to preserve the entire undissolved residue. Therefore, the objectives of the study were: (1) to find the most effective reagent rinsing method which follow the dissolution of (oxy)hydroxides using dithionite-citrate-bicarbonate; and (2) to test if the content of Fe (oxi)hydroxides could be determined gravimetrically. The purpose of the study was to optimize the analytical methods used in our laboratory. The following reagent rinsing methods were tested: (1) centrifugation, (2) filtration, (3) dialysis.

\section{Materials and Methods}

The analysed sample (K-2; laboratory number 4954) represents a $\mathrm{B}$ horizon of polygenetic soil developed on Cretaceous limestone at the site Dobranje in the hinterland of the Neretva River valley, $7 \mathrm{~km}$ north-east of the lake Kuti. The sample location is designated as shallow terra rossa on the Basic Soil Map - sheet Mljet 2 (Martinović, 1978).

The moisture content of the sample was determined from weight loss on drying at $105^{\circ} \mathrm{C}$ for $24 \mathrm{~h}$. Sample preparation included: (1) removal of possible traces of carbonates using 5\% acetic acid (followed by 5 times rinsing with distilled water and centrifugation at 3800 rpm for 15 minutes); and (2) removal of organic matter using 30\% hydrogen peroxide (followed by evaporation). The obtained material was milled in an agate mortar. Mineral content of the original sample, as well after carbonate and organic matter removal, was determined using X-ray diffraction (Philips diffractometer PW1710).

Further, material left was divided in 9 sub-samples. All nine sub-samples were subjected to dissolution of (oxy)hydroxides using dithionite-citrate-bicarbonate (DCB) as follows:
$1 \mathrm{~g}$ of each sub-sample was treated with $40 \mathrm{ml}$ of 0.3 $\mathrm{M}$ sodium citrate and $10 \mathrm{ml}$ of $1 \mathrm{M}$ sodium bicarbonate solution and heated on a water bath at temperature of $80^{\circ} \mathrm{C}$ for 15 minutes. After heating, $0.5 \mathrm{~g}$ of sodium dithionite was added and allowed to react. Addition of sodium dithionite was repeated after 15 minutes and again left to react. Reaction caused fading of the sample color. After cooling, the sample was centrifuged at $3800 \mathrm{rpm}$, 10 minutes, and the supernatant was decanted into a volumetric flask. Concentrations of iron in supernatants were analyzed by flame atomic absorption spectroscopy (AAnalyst 700 Perkin Elmer) using an iron hollow cathode lamp at wavelength 302.1. The insoluble residues were mixed with $50 \mathrm{ml}$ of distilled water and dispersed. Three sub-samples were used for the testing of each rinsing method: centrifugation, filtration and dialysis. The fraction of soil which was dissolved by reduction (DCB treatment) is named "the reducible fraction". This fraction is mainly composed of Fe (oxi)hydroxides. It can contain traces of Mn (oxi)hydroxides and other phases soluble in a reductive environment.

\subsection{Rinsing by centrifugation}

Three sub-samples (A1, A2 and A3) were centrifuged at $3800 \mathrm{rpm}$ for 20 minutes. After the first centrifugation the supernatant was not clear, therefore the centrifugation was prolonged for 20 minutes. Still the supernatant was not clear. At this point, the supernatant was decanted in beakers, and sub-samples were rinsed with another 50 $\mathrm{ml}$ of distilled water by centrifugation at $3800 \mathrm{rpm}$ for 40 minutes. The second supernatant was more limpid than the first one. The content of colloidal particles was monitored by measuring the transmittance at $550 \mathrm{~nm}$ using Specol 1100 spectrophotometer (Analytik Jena AG, Germany). Rinsing was repeated five times. Supernatants were tested for the presence of sulphate using 0.1 $\mathrm{M} \mathrm{BaCl}_{2}$. The test was negative in the fifth supernatant. The process of rinsing using centrifugation followed by decantation lasted roughly 4 hours. All three sub-samples were dried and weighed.

\subsection{Rinsing by filtration}

Filtration was performed using "Blue Ribbon" filter paper (IDL GmbH \& Co. KG Laborgroßhandel für Europa) designed for filtering suspensions of small particles. For 1 sub-sample (B1) one filter paper was used, while for the two other sub-samples (B2 and B3), two filter papers were used. However the particles were too small, and they passed through both filter papers. Therefore, the filtrate was returned into the funnel. Even after the second filtration, the filtrate was not clear. To accelerate the filtration reduced pressure was used. The initial filter paper was used till the end of the filtration. The presence of sulphate was tested using $0.1 \mathrm{M} \mathrm{BaCl}_{2}$. Rinsing by filtration using filter paper lasted roughly 7-8 hours. All three sub-samples were dried and weighed. 


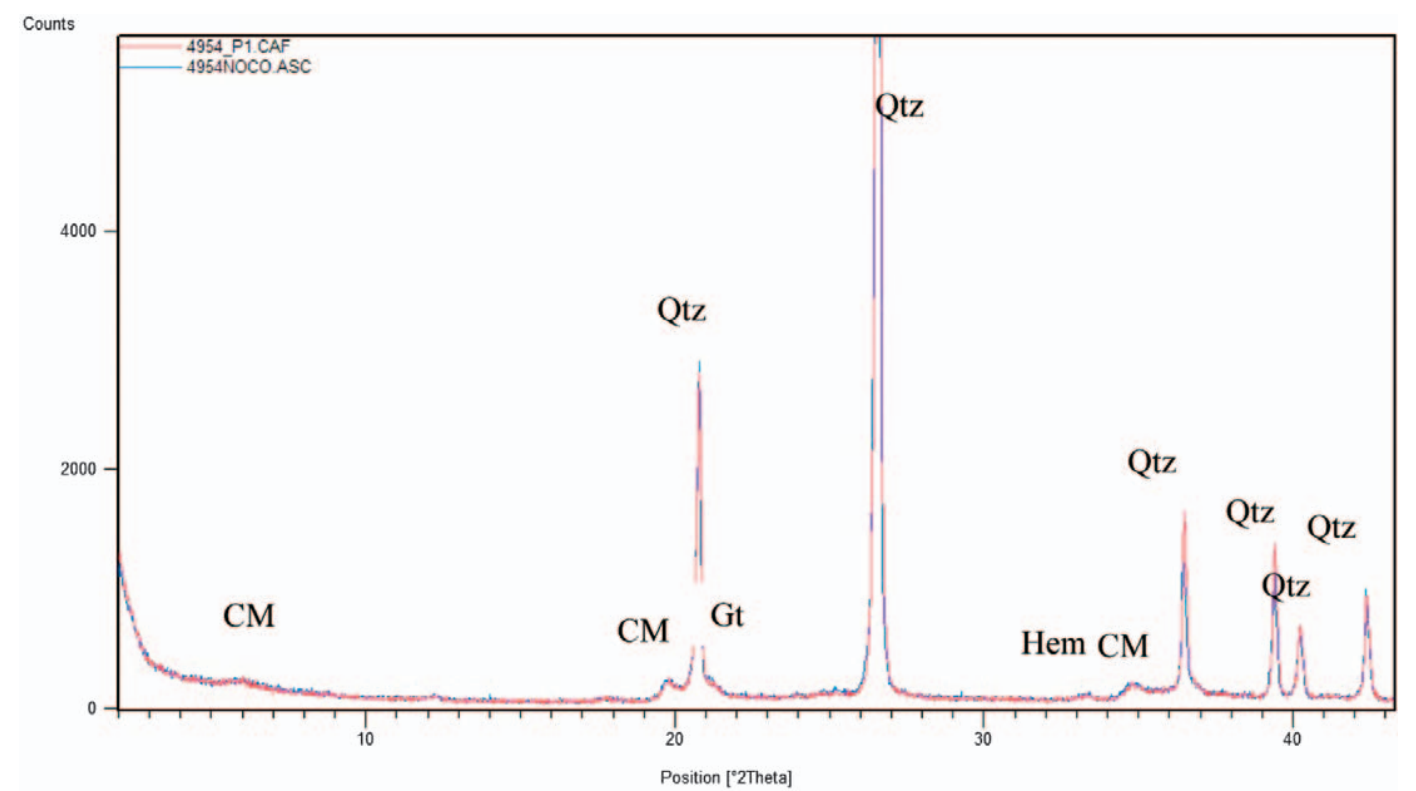

Figure 1: The diffraction patterns of the terra rossa sample prior to and following acetic acid and hydrogen peroxide treatments (Legend: red - original sample, blue - insoluble residue, CM - clay minerals; Qtz - quartz, Gt - goethite; Hem - haematite).

\subsection{Rinsing by dialysis}

Dialysis, a common laboratory technique, is the process of separating molecules in a solution by the difference in their rates of diffusion through a semipermeable membrane, such as dialysis tubing. Among different uses, its most common application is for the removal of unwanted small molecules. In this study, dialysis tubing (19.00 mm, Medicell International Ltd., London) were first soaked in distilled water. Subsequently, the three sub-samples suspensions were poured into the dialysis tubing, tied and placed in a beakers with distilled water. Conductivity of distilled water, as well as water in which dialysis tubing was immersed, was measured using a conductivity meter (WTW Multi 340i - oximeter conductivity meter $\mathrm{pH}$ meter, WTW Germany). The water in the beaker was exchanged till the water after soaking did not change its conductivity. All three sub-samples were dried and weighed. After homogenization in the agate mortar, XRD analysis of the subsamples was performed.

\section{Results and Discussion}

\subsection{Characterisation of analysed sample}

The analysed sample of terra rossa soil contains quartz, hematite, goethite and clay minerals. After acetic acid and hydrogen peroxide treatments, there was no change in diffraction pattern (see Figure 1). The moisture content of the sample was $2.08 \pm 0.02 \%$. The $\mathrm{Fe}_{2} \mathrm{O}_{3}$ content, recalculated from the concentration of iron determined by atomic absorption spectroscopy after dissolution of sub-samples in the dithionite-citrate-bicarbonate, is presented in Table 1. Each sub-sample was
Table 1: Iron (oxy)hydroxide content of the sub-samples determined by atomic absorption spectrometry

\begin{tabular}{|l|c|}
\hline Sub-sample & $\mathbf{F e}_{\mathbf{2}} \mathbf{O}_{\mathbf{3}} \mathbf{( \% )}$ \\
\hline A1 & 4.86 \\
\hline A2 & 5.52 \\
\hline A3 & 5.14 \\
\hline B1 & 4.91 \\
\hline B2 & 5.27 \\
\hline B3 & 5.28 \\
\hline C1 & 5.13 \\
\hline C2 & 5.10 \\
\hline C3 & 5.16 \\
\hline
\end{tabular}

measured in triplicate. Relative standard deviations (RSD) for all sub-samples are below $1 \%$. The mean value of $\mathrm{Fe}_{2} \mathrm{O}_{3}$ content is $5.12+/-0.10 \%$.

\subsection{The reducible fraction content in analysed sample determined by gravimetric analysis}

Efficiency of iron (oxy)hydroxide removal is presented in Figure 2. The reducible fraction content determined by gravimetric analysis following the different rinsing methods is presented in Table 2 and Figure 3.

\section{Centrifugation}

The subsamples (A1-A3) were rinsed 5 times with the distilled water to completely remove all electrolytes (the removal was proven by barium chloride). Following each rinsing step, the transmittance of the supernatant 

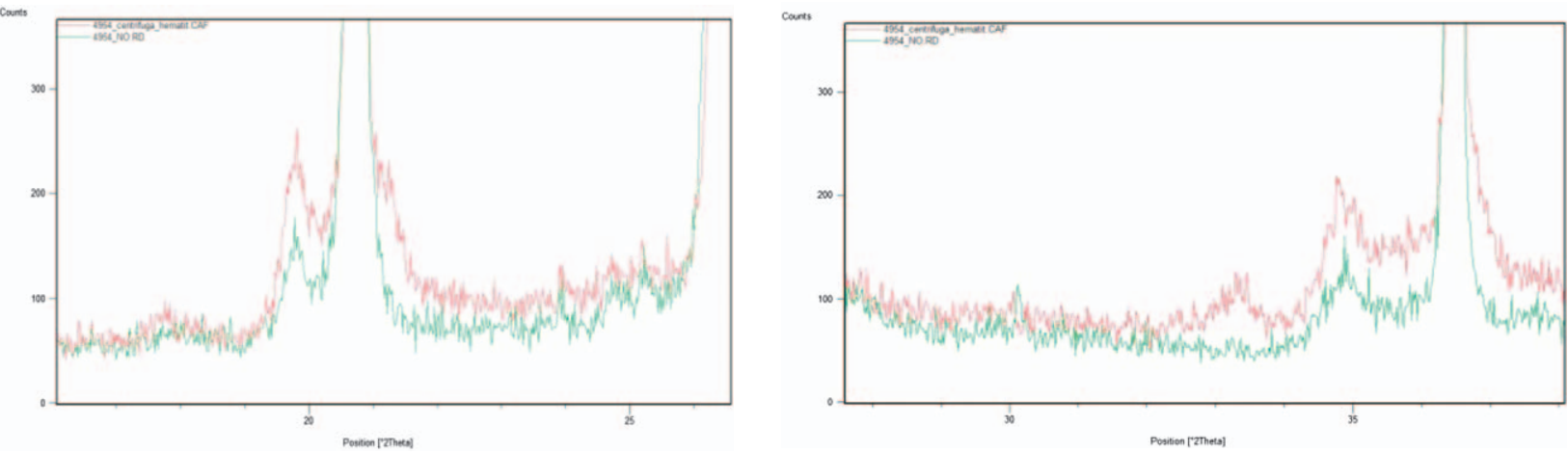

Figure 2: The diffraction patterns of the terra rossa sample prior to and following DCB treatment (Legend: red - original sample, green - insoluble residue).

Table 2: Reducible fraction content of the sub-samples determined by gravimetric analysis after different rinsing methods

\begin{tabular}{|l|c|c|c|}
\hline $\begin{array}{l}\text { Rinsing } \\
\text { method }\end{array}$ & Sub-sample & $\mathbf{F e}_{\mathbf{2}} \mathbf{O}_{\mathbf{3}} \mathbf{( \% )}$ & Mean (\%) \\
\hline \multirow{4}{*}{ Centrifugation } & $\mathbf{A 1}$ & 21.43 & \\
\cline { 2 - 4 } & $\mathbf{A 2}$ & 27.37 & $22.89+/-4.48$ \\
\cline { 2 - 4 } & $\mathbf{A 3}$ & 19.86 & \\
\hline \multirow{3}{*}{ Filtration } & $\mathbf{B 1}$ & 29.53 & \\
\cline { 2 - 4 } & $\mathbf{B} 2$ & 29.16 & $28.69+/-1.34$ \\
\cline { 2 - 4 } & $\mathbf{B 3}$ & 27.32 & \\
\hline \multirow{3}{*}{ Dialysis } & $\mathbf{C 1}$ & 6.13 & \\
\cline { 2 - 4 } & $\mathbf{C 2}$ & 5.62 & $7.76+/-3.71$ \\
\cline { 2 - 4 } & $\mathbf{C 3}$ & 11.53 & \\
\hline
\end{tabular}

was measured (see Table 3) in order to determine the effectiveness of the centrifugation. The transmittance data showed that the most incoming radiation passed through the supernatant after the first three steps; this indicated a significant particle content in supernatant after the fourth and fifth steps of rinsing, which reflected a loss of material.

Hence, centrifugation is a rapid method (it lasted 4 hours in total), but it can lead to a loss of material, particularly of the smallest particles. High sedimentation speeds and/or longer centrifugation times are needed to ensure complete sedimentation of submicron particles. The difficulties with highly dispersed suspensions may be overcome by adjusting the $\mathrm{pH}$ of the rinsing water close to the point of zero charge (PZC) of the oxide (usually $\mathrm{pH}$ 7-8). In that case, flocculation is facilitated (Schwertmann and Cornell, 2000).

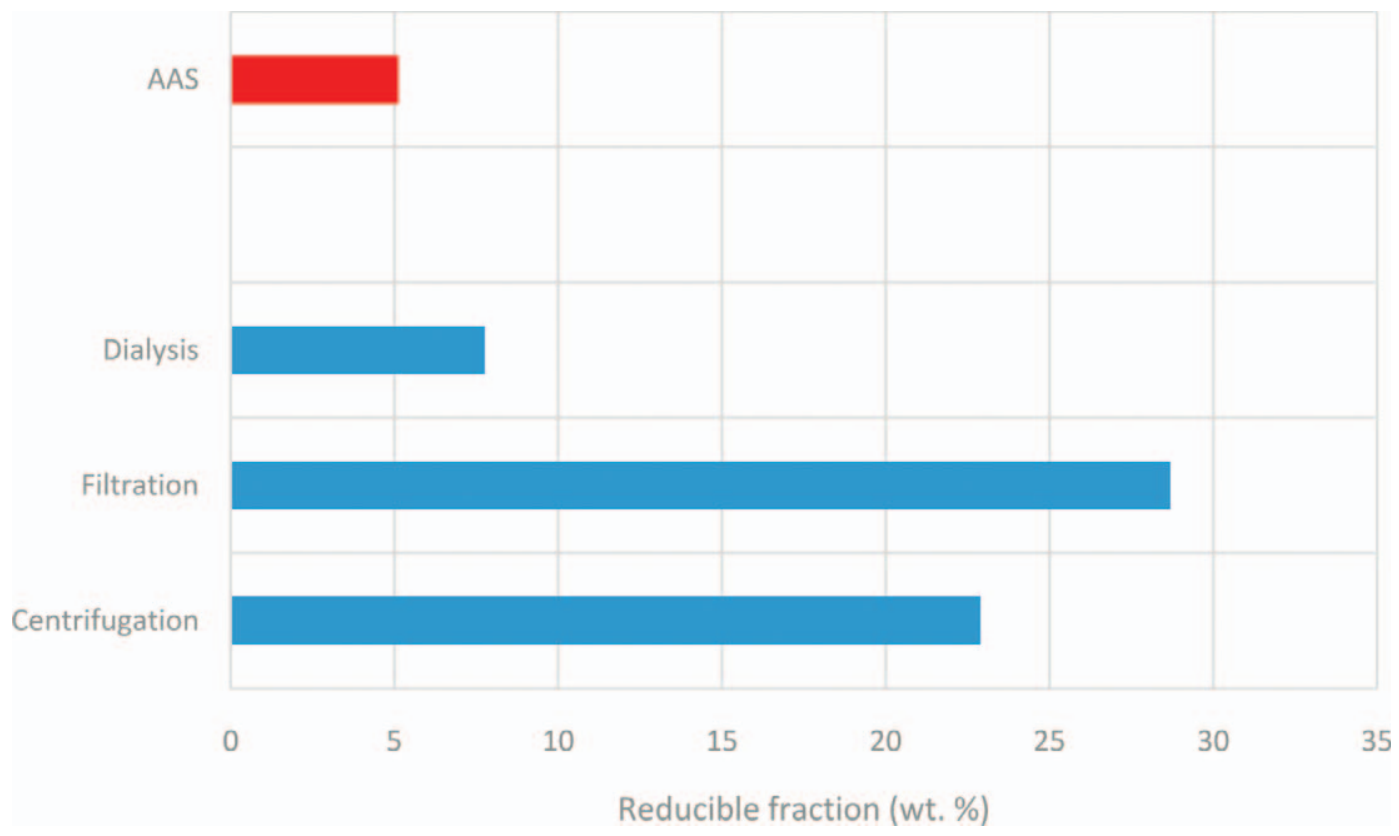

Figure 3: Mean values of the reducible fraction content (blue) determined gravimetrically after DCB dissolution followed by the different rinsing methods (Red rectangle represents $\mathrm{Fe}_{2} \mathrm{O}_{3}$ content in wt. \% calculated from iron concentrations in DCB extract). 
Table 3: The transmittance data after each step of centrifugation (\%)

\begin{tabular}{|l|c|c|c|}
\hline Rinsing step & A1 & A2 & A3 \\
\hline 1 & 78.64 & 62.60 & 85.43 \\
\hline $\mathbf{2}$ & 79.41 & 73.48 & 88.73 \\
\hline $\mathbf{3}$ & 64.36 & 67.98 & 85.01 \\
\hline $\mathbf{4}$ & 40.00 & 47.52 & 64.72 \\
\hline $\mathbf{5}$ & 36.43 & 24.83 & 46.76 \\
\hline
\end{tabular}

\section{Filtration}

Although filtration was performed using the "Blue Ribbon" filter paper designed for filtering suspensions of very small particles, it was found to be an inefficient rinsing method. Therefore, two filter papers were used for the sub-samples B2 and B3. However, the particles were too small, and they passed through both of them. Hence, the filtration using $0.45 \mathrm{pm}$ millipore filter under vacuum should be tested. Though, in the case of large quantities of suspension or with very small particles (e. g. ferrihydrite), the clogging of the filter pores makes the method impracticably slow (Schwertmann and Cornell, 2000).

\section{Dialysis}

Dialysis was found to be the most effective rinsing method. However, the colour of the solution in the dialysis tubing after rinsing was not clear, but beige in colour. The conductivity measurements (see Table 4) and rinsing were performed till the conductivity of the surrounding water was equal to that of distilled water. The disadvantage of dialysis was the long duration time of its completion which lasted 1 week.

Table 4: Electrical conductivity $(\mu \mathrm{S} / \mathrm{cm})$ of the rinsing water during dialysis

\begin{tabular}{|l|c|c|c|}
\hline Rinsing (hours) & C1 & C2 & C3 \\
\hline 0 & 8 & 8 & 8 \\
\hline 24 & 236 & 230 & 184 \\
\hline 48 & 35 & 41 & 27 \\
\hline 72 & 26 & 25 & 23 \\
\hline 120 & 15 & 15 & 13 \\
\hline
\end{tabular}

\section{Conclusion}

Iron (oxy)hydroxides represent one of the most important groups of minerals in the context of environmental geochemistry and mineralogy. Being secondary minerals, formed at the surface conditions as weathering products of ferromagnesian rock minerals, they are usually very small in size (large specific surface area) and have defects in the structure (often positively charged). Hereby, they greatly adsorb nutrients as well as poten- tially toxic elements. This study was focused on the rinsing methods following the DCB selective leaching procedure widely used for: 1/ quantification; 2/ sample preparation for clay analysis; and 3/ determination of coprecipitated trace elements. The following reagent rinsing methods were tested: (1) centrifugation, (2) filtration, (3) dialysis. The analysis was conducted on the red soil sample containing $5.12 \% \mathrm{Fe}_{2} \mathrm{O}_{3}$. The time needed for rinsing increased in the order: centrifugation $(4 \mathrm{~h})$ $<$ filtration $(7 \mathrm{~h})<$ dialysis (1 week). The amount of gravimetrically determined dissolved reducible fraction upon rinsing varied significantly depending on the method and it was remarkably higher than the amount of $\mathrm{Fe}_{2} \mathrm{O}_{3}$ determined by analysing iron content in leachate. The most effective reagent rinsing method which followed the dissolution of (oxy)hydroxides using dithionite-citrate-bicarbonate was found to be dialysis. No loss of sample is the advantage of this method, but its disadvantage was the time needed for its completion. The centrifugation was relatively rapid, but it can lead to a loss of the smaller particles. In this case the loss was unacceptably high. The filtration using filter paper was more time consuming than the centrifugation, and it showed the least acceptable results. Filtration using the $0.45 \mathrm{pm}$ millipore filter under vacuum conditions will be tested in the future. It should be relatively rapid and satisfactory, especially for samples with a significant amount of small particles.

The following conclusions can be drawn from this study:

1) The content of Fe (oxi)hydroxides cannot be determined gravimetrically upon selective leaching.

2) Rinsing of reagents after Fe (oxi)hydroxides removal prior to clay mineral analysis should be carefully selected and performed, especially in the case of small particle presence (e.g. smectites).

3) Centrifugation, the commonly accepted rinsing method in all sequential extraction procedures, can lead to incorrect results. Hence, to accomplish sedimentation, higher speed or longer centrifugation times are necessary in some cases.

\section{Acknowledgments}

This work has been fully supported by Croatian Science Foundation under the project 2504 - NanoMin (Nanominerals in sediments and soils: formation, properties and their role in biogeochemical processes).

\section{References}

Borggaard, O.K. (1979): Selective extraction of amorphous iron oxides by edta from a danish sandy loam. European Journal of Soil Science, 30/4, 727-734. (DOI: 10.1111/ j.1365-2389.1979.tb01022.x)

Burgos, W.D., Borch, T., Troyer, L.D., Luan, F., Larson, L.N., Brown, J.F., Lambson, J. and Shimizu, M. (2012): Schw- 
ertmannite and $\mathrm{Fe}$ oxides formed by biological low-pH $\mathrm{Fe}(\mathrm{II})$ oxidation versus abiotic neutralization: impact on trace metal sequestration. Geochimica Cosmochimica Acta, 76, 29-44. (DOI: 10.1016/j.gca.2011.10.015)

Durn, G. Slovenec, D. and Čović, M. (2001): Distribution of Iron and Manganese in Terra Rossa from Istria and its Genetic Implications. Geologia Croatica, 54, 1, 27-36.

Martinović, J., Jakšić, V. and Kapisazović, G. (1978): Pedološka karta SFRJ, mjerilo 1:50000, list Mljet 2 (Basic Soil Map of SFRJ, scale 1:50000 - sheet Mljet 2), Izdavač OOUR Zavod za agropedologijju Sarajevo i Projektni Savjet za izradu pedološke karte Hrvatske.

Mehra, O.P. and Jackson, M. L. (1960): Iron oxide removal from soils and clays by a dithionite-citrate system buffered with sodium carbonate. Seventh National Conference on Clays and Clay Minerals, 7, 317-327. (DOI: 10.1346/ CCMN.1958.0070122)

Miko, S., Durn, G., Adamcová, R., Čović, M., Dubíková, M., Skalský, R., Kapelj, S. and Ottner, F. (2003): Heavy metal distribution in karst soils. Environmental Geology, 45/2, 262-272. (DOI: 10.1007/s00254-003-0878-y)

Mileusnić, M., Mapani, B.S., Kamona, A.F., Ružičić, S., Mapure, I. and Chimwamurombe, P.M. (2014): Assessment of agricultural soil contamination by potentially toxic metals dispersed from improperly disposed tailings, Kombat mine, Namibia. Journal of geochemical exploration, 144/C, 409-420. (DOI: 10.1016/j.gexplo.2014.01.009)
Rauret, G., López - Sánchez, J. F., Lück, D., Yli - Halla, M., Muntau, H. and Quevauviller, P. H. (2001): The certification of the extractable contents (mass fractions) of $\mathrm{Cd}, \mathrm{Cr}$, $\mathrm{Cu}, \mathrm{Ni}, \mathrm{Pb}$ and $\mathrm{Zn}$ in freshwater sediment following sequental extraction procedure BCR-701. European Commision, Belgium. ISBN 92-894-0755-7.

Schwertmann, U. (1964): Differenzierung der Eisenoxide des Bodens durch photochemische Extraktion mit saurer Ammoniumoxalat-lösung. Zeitschrift für Pflanzenernährung und Bodenkunde, 105, 194-202. (DOI:10.1002/jpln.359 1050303)

Schwertmann, U. and Cornell, R.M. (2000): Iron Oxides in the Laboratory. Preparation and Characterization. Second, Completely Revised and Extended Edition. Wiley - VCH Verlag GmbH, D-69469 Weinheim (Federal Republic of Germany), 188 p.

Schwertmann, U., Murad, E. and Schulze, D.G. (1982): Is there Holocene reddening (hematite formation) in soils of oxeric temperate areas?. Geoderma, 27, 209-223.

Schwertmann, U. and Taylor, R.M. (1989): Iron Oxides: Minerals in Soil Environments. Second Edition. Soil Science Society of America, Co-Editors: J.B. Dixon \& S.B. Weed, 379-438.

Tessier, A., Campbell, P.G.C. and Bisson, M. (1979): Sequential extraction procedure for the speciation of particulate trace metals. Analytical Chemistry, 51 (7), 844-85. (DOI: 10.1021/ac50043a017)

\section{SAŽETAK}

\section{Usporedba različitih metoda ispiranja nakon selektivnoga otapanja željezovih (oksi)hidroksida u tlima/sedimentima}

Željezovi (oksi)hidroksidi imaju važnu ulogu u različitim disciplinama, među ostalim u zaštiti okoliša, prospekciji rudnih ležišta, mineralogiji, geologiji i pedologiji. U postupcima selektivnoga otapanja, bilo da su namijenjeni uklanjanju (oksi)hidroksida prije analize minerala gline ili za određivanje metala u reducirajućoj frakciji tla/sedimenta, vrlo je važno sačuvati cijeli neotopljeni ostatak. Stoga su ciljevi ovoga rada bili: (1) odrediti najučinkovitiju metodu ispiranja reagensa nakon otapanja (oksi)hidroksida i (2) provjeriti može li se sadržaj željezova (oksi)hidroksida odrediti gravimetrijski. Testirane su sljedeće metode ispiranja: (1) centrifugiranje, (2) filtriranje, (3) dijaliza. Analiza je provedena na uzorku crvenice koji sadržava 5,12 \% Fe2O3. Vrijeme potrebno za ispiranje povećava se ovim redoslijedom: centrifugiranje < filtriranje < dijaliza. Udio gravimetrijski određene otopljene frakcije znatno se razlikuje ovisno o odabranoj metodi ispiranja te je neusporedivo veći od udjela $\mathrm{Fe}_{2} \mathrm{O}_{3}$ određenoga mjerenjem željeza u ekstraktu nakon otapanja. Najučinkovitija metoda ispiranja ditionit-citrat-bikarbonata nakon otapanja (oksi)hidroksida jest dijaliza. Prednost je ove metode $u$ tome što nema gubitka uzorka, a nedostatak je vrijeme potrebno za njezino provođenje. Centrifugiranje je relativno brza metoda, no može dovesti do gubitka sitnih čestica. U ovome istraživanju gubitak je bio neprihvatljivo velik. Filtriranje pomoću filtarskoga papira oduzima više vremena od centrifugiranja te je pokazalo najlošije rezultate. Na temelju rezultata možemo zaključiti: (1) sadržaj željezova (oksi)hidroksida ne može se odrediti gravimetrijski nakon selektivnoga otapanja; (2) način ispiranja reagensa nakon uklanjanja željezova (oksi)hidroksida pri pripremi uzoraka za analizu minerala glina treba biti pažljivo odabran i izveden; (3) centrifugiranje, uobičajena metoda ispiranja u svim postupcima sekvencijske ekstrakcijske analize, može dovesti do krivih rezultata.

\section{Ključne riječi}

željezovi (oksi)hidroksidi, ispiranje, centrifugiranje, filtriranje, dijaliza 